\title{
Controlling marriages: Friedrich Hagenauer and the betrothal of Indigenous Western Australian women in colonial Victoria
}

\author{
Felicity Jensz
}

Throughout the colonial world, sex, sexuality and intimacy were topics of intense scrutiny. ${ }^{1}$ In colonial spaces sexual control was, according to Ann Laura Stoler, a method in which colonial authorities could regulate not only the lives of the Europeans within colonial spaces, but also the lives of Indigenous peoples. ${ }^{2}$ Missionaries were also very concerned with the sexuality and sexual practices of the people amongst whom they worked, and often saw the female sexuality of indigenous peoples as being in need of controlling and according to Christian norms. Missionaries had long expected their converts to conform to Christian moral codes relating to sex and sexuality. The historian Gorden Sayre has asserted in the context of seventeenth century northern America that 'missionaries took the well-defined Christian separation between the chaste and the unchaste and used it as an analogy for the distinction between the converted and unconverted around their mission. ${ }^{3}$ Such sentiments seeped into the nineteenth century in all corners of the globe. Chastity was seen as a sign of a docile and regenerate people, and conversely, promiscuous behaviour was a sign of rebellion and a lack of respect for authority and Christian norms. Natasha Erlank has argued that missionaries in the 1840s in Xhosaland, South Africa lacked methods of enforcing upon the converts their preferred sexual codes and therefore used 'the control of spiritual resources to punish converts.' ${ }^{4}$ Such control included refusal of baptism, excommunication, and suspension from positions of moral authority. This paper argues that not only exclusion from but also inclusion within Christian practices served as forms of punishment for Indigenous people seen to be at odds with the moral practices and sexual codes expected on a mission station. In particular, this paper contends that the arranged marriages of Indigenous females on Moravian mission stations in the Colony of Victoria in the mid-nineteenth century was undertaken by the missionary in charge in order to control the sexuality of these women.

These women - Rhoda Toby, Nora White, Emily Peters and Ada Flower - had been sent some 3,500 kilometres from the west coast of Australia to the other side

1 Ballantyne and Burton 2009: 4.

2 Stoler 1989: 635.

3 Sayre 1998: 39.

4 Erlank 2003: 76. 
of the continent with the hope that they would be good role models for Gunai/ Kurnai women on the Ramahyuck mission station in Gippsland in the east of the Colony of Victoria. They were, however, quickly married off in an attempt to control and subdue them, primarily because their behaviour conflicted with the strict moral code of the missionary, Friedrich Hagenauer. Hagenauer himself was one of the most important missionaries in colonial Victoria, as well as being a member of the colonial government's Board for the Protection of the Aborigines. ${ }^{5}$ In order to contextualise the marriages of these women, this paper will examine what marriage specifically meant for Moravian missionaries, before it progresses to examine the marriage prospects of the first three male converts of the Victorian Moravian mission stations, and then finally the paper will examine the marriages of these women in light of the religious, gendered and racial expectations placed upon them.

\section{Moravians and the institution of marriage}

The Moravian Church was reformed in the eighteenth century on the estate of Count von Zinzendorf, who himself had a strong pietistic upbringing. His influence ensured that the Moravian Church had strong links to the pietistic tradition of eighteenth century Germany as well as to the evangelical awakening of eighteenth century Britain. ${ }^{6}$ Marriage was practised within the Church as a sacred institution incarnating the glory of God. As within broader eighteenth and nineteenth century European practices, marriage signified a monogamous relationship between a male and a female, which privileged the nuclear family over larger social groupings. Particularly within the Moravian Church one of the functions of marriage was to allow Church members to become more unified with God through marital sex, which was seen as an act of glorifying God. ${ }^{7}$ The Church maintained a strict control over gender relationships throughout the eighteenth century and it was at the discretion of the Church Elders that marriages were arranged. These arranged marriages were considered by the Elders, who took their decision to the Lord in the form of a lot, which was usually comprised of drawing one of three tokens either imprinted with a 'yes' or a 'no', or a third, blank token. ${ }^{8}$ According to the nineteenth century Moravian historian John Holmes, the Church Elders did not invest authority in 'any man' rather applied 'for direction to the Lord himself, by the use of the lot.' ${ }^{\prime}$ Thus, the practice of drawing a lot to endorse marriage was deemed to be an extension of the Lord's decisions, however, it was also a source of discontent for some members. During the nineteenth century this practice was discontinued for common members, yet the lot continued to be used to arrange marriages for missionaries until the end of the nineteenth century. ${ }^{10}$

5 Jensz 2010: esp Chapter 6; Blake 1972: 314-315.

6 Podmore 1998: esp Chapter 4.

7 Peucker 2006: 30-64.

8 Bettermann 1931: 284-287; Beyreuther 1962: 109-135.

9 Holmes 1818: 286.

10 Mettele 2009: 130. 
Since the beginning of the Church, missionary workers - both single and married - had been sent out in order to bring the Christian word to the 'heathen'. By the 1870s there were over 300 missionaries in the field, amongst whom were often single men, who were only allowed to marry within the Church. As the men had often spent many years away from Europe, they often were not aware of potential mates and could not offer the Church administrators the names of prospective spouses. The Church Elders, with the help of the lot, thus facilitated such marriages. ${ }^{11}$ Once the decision of lot was in favour of a particular potential bride for a missionary, the Elders invited the sister to accept the offer of marriage. She was, however, free to reject the offer if she did not deem it suitable for her, giving women agency in their own destinies. Moravian women were seen as missionaries in their own right, as well as being seen as wives, mothers, role models, and also confidants for indigenous women on mission stations. The historian Amy Schutt has argued that, within the context of eighteenth century Moravian Indian missions in America: 'gender identification helped bridge cultural differences and gave Indian and Euro-American women entrée into each other's worlds. ${ }^{\prime 2}$ By the nineteenth century, however, Moravian missionary practices had become more patriarchal, as Moravians mirrored the contemporary gender politics of other Protestant missionary organisations. ${ }^{13}$ The roles of female missionaries were consequently diminished, with the result that their work was deemed inferior to that of male missionaries. Nonetheless, women of both Western and Indigenous heritages were necessary and important members of a mission station, as their roles on the mission reflected broader societal structures.

Friedrich Hagenauer, along with his colleague Friedrich Wilhelm Spieseke, had been sent out in 1859 to Australia as unmarried men to establish the Ebenezer mission station in the north-west of the Colony of Victoria in the hope of converting the Wotjobaluk to Christianity. Within the Moravian framework, the Australian Aborigines were seen as being in particular need of the Christian message as they were deemed 'poor, despised creatures, who are on the lowest level' ${ }^{14}$ of both of cultural and religious scales. Through introducing the values, norms, and practices inherent in both Christianity and Western European civilisation, it was expected that missionaries would 'raise' Aborigines to the level of Europeans. In the early and uncertain stages of this mission field, the Church administration had deemed the cost of sending out and supporting married couples to be prohibitive. ${ }^{15}$ However, sending out only single male missionaries ensured that the focus of the missionaries' endeavour was placed on proselytising the Indigenous men. The administration cautioned against lone male missionaries conversing with female 'heathens', and it was expected that

11 See for example Jensz 2010: 132-133.

12 Schutt 2004: 87-103.

13 Schutt 2004: 102-103.

1423 February 1841, \#5, Protocoll der Unitätsaeltesten Conferenz [hereafter PUAC], Unitätsarchiv, Herrnhut, Germany [hereafter UA].

151 June 1853, \#8, Protocoll des Missionsdepartements [hereafter PMD], UA; 15 June 1853, \#11, PMD, UA; 15 November 1854, \#12, PMD, UA; 29 May 1852, \#6, PUAC, UA. 
if a male missionary was to converse with 'heathen' females, it 'must always be done in the presence of his wife. ${ }^{\prime 16}$ According to the nineteenth-century British Moravian, Mrs EH Hassé:

One lesson which [the Moravians] soon learnt was, that, not only is it not good for a man to be alone, but that this is especially so in the polluted moral atmosphere of heathendom, and further, that man's work is best done when according to the Divine ordinance, it is with women as his helpmeet. ${ }^{17}$

Within the Australian mission field this lessen was demonstrated aptly through the experiences of Job Francis, a 22-year-old unmarried missionary. Francis arrived at Ebenezer in November 1861, to help run the day school. ${ }^{18}$ He soon complained bitterly to the headquarters of the Church in Germany about the 'adulterous eyes' of the Indigenous women in the camps, adding that he could not work with them. He maintained that most of them had 'had connections with white men', and thus were 'repulsive to my nature. ${ }^{\prime 19}$ If only he were sent a wife, he declared, he would be able to overcome this 'hindrance' ${ }^{20}$ Francis's description of Indigenous women, and his subsequent request for a wife of his own, reflected the binary positioning of women in his world-view as either sexually immoral women or wives. It also reflected a belief more generally held amongst both Moravian men such as Francis, and Moravian women such as Hassé, that 'heathendom' was associated with lax morality, and that such undesired traits of a race could be conquered if the 'heathens' - especially the females as the perceived bastions of European family values - were to adapt and subscribe to new religious understandings which reflected a Western world-view and control of sexuality through marriage. Indigenous women were therefore more likely - in the male missionaries' imagination and descriptions - to occupy the role of the immoral, licentious woman than that of wife of a missionary. This was especially so in the nineteenth century as missionaries were only allowed to marry Moravian Sisters known by the Church administration. ${ }^{21}$ Francis's confessed inability to work amongst Indigenous women as a single man speaks of his awareness of his own sexuality, and the threat that he believed Indigenous women posed towards it.

The Moravian Church did not send out a wife for the 22-year-old Francis and he subsequently left the Church after marrying a non-Moravian without permission from the Church Elders. ${ }^{22}$ Some years before, during the early days

16 Spangenberg 1840: 50. This booklet was addressed to both male and female missionaries collectively, with no specific directions to female missionaries.

17 Hassé 1897: 4.

1825 January 1862, \#14, PUAC, UA.

19 Francis to Reichel, 10 December 1861, Moravian Microfilm Collection (MF) 177, Aboriginal Affairs Victoria.

2024 July 1862, \#15, PUAC, UA.

21 In eighteenth-century North America there were examples of Moravian missionaries marrying indigenous converts, however, this trend does not seem to be followed in the nineteenth century. See Wheeler 2006: 90.

22 Jensz 2010: 145-146. 
of the Ebenezer mission station, Hagenauer and Spieseke had requested wives to be sent to help them in their spiritual work on the mission, especially their work with female Aborigines. ${ }^{23}$ Friends of the missionaries within Australia, who were less aware of the pastoral role of Moravian women, wrote to the Moravian Church suggesting that wives were needed to help in the domestic sphere in order for the male missionaries to gain more time to proselytise. ${ }^{24}$ After some hesitation, and many drawings of the lot, the Church sent out the Moravian Sisters Christine Louise Knobloch and Christine Fricke from Germany. They arrived in Melbourne early in 1861, and soon thereafter began their work as female missionaries amongst Indigenous Australians, with Knobloch working at Ramahyuck with her husband Hagenauer and Fricke at Ebenezer with her husband Spieseke. ${ }^{25}$

The formal union of a heterosexual couple was also important in traditional Aboriginal life, ensuring the continuation of lineage and of social structures. Traditional marriage practices amongst Aboriginal Australians differed in various geographical locations depending on clan association, with intricate rules enacted to ensure the maintenance of complex social structures as well as to ensure exogamy. In a book published at the turn of the twentieth century, which was compiled from material collected over the preceding four decades or more, the anthropologist AW Howitt presented his postulations and observations on Aboriginal marriage customs. In his analogy, traditional Aboriginal marriage customs were as if 'an English village had determined that its children should marry beyond its bounds, the sons bringing their wives to the village, while the daughters went to the villages whence their brothers took their wives' ${ }^{26}$ Marriage was thus not seen as primarily a personal decision, rather as a public or communal decision undertaken to engender exogamy as well as to strengthen ties between communities. In his specific writings on the Gunai/Kurnai nation, which comprised the broader social and political category to which the men at the second Moravian mission in Victoria, the Ramahyuck mission station, belonged, he stated that men 'could acquire a wife in one way only, namely, by running off with her secretly and with her own consent', ${ }^{27}$ thus reflecting individual agency and the norms of romantic love popular within middle class Victorian England. Yet, as we shall read below, when the Moravian missionaries imposed their ideas of Christian marriage onto Kurnai men and Western Australian women, it did not mirror contemporary ethnographical thought, for on the mission station marriage was not intended to facilitate the reciprocity of the English village scenario, nor was it a secret pact between two willing individuals. For the missionaries, intra-racial marriages of Indigenous peoples on the mission stations were relationships forged under European understandings of the sanctity of the

2319 May 1859, \#22, PUAC, UA. See also, Missionsblatt, No 6, 1859, p. 116. In this passage Old Charley states that he would like to bring his daughter to the mission so that she can be schooled by the missionaries. As they were single, however, they did not feel able to teach her.

244 March 1860, \#6, PUAC, UA.

254 April 1860, \#9, PUAC, UA; 4 March 1860, \#6, PUAC, UA.

26 Howitt 1996[1904]: 11.

27 Howitt 1996[1904]: 273. 
institution of marriage in relation to Christian norms and gendered European normative codes of behaviour for individuals within this institution. Moreover, the partners within these marriages were expected to be good role models to the as-yet un-converted and un-married people on the mission.

\section{A precedent is set: Rachel Wardekan, Caroline, and Anna}

The conversion to Christianity of the Wotjobaluk youth, Nathanael Pepper, on the Ebenezer mission station in 1860 led the missionaries to contemplate a potential wife for him in order that he would be able to live a good Christian life and provide 'a good example to the Blacks' ${ }^{28}$ Unlike their own marriages, where brides were chosen through the drawing of the lot, Pepper's wife was chosen for him by the missionaries. Through choosing a bride for him, the missionaries took control over Pepper's private life and bound him to them through this act. The missionaries were constrained by religious, class and racial categories in considering a bride for Pepper as they desired a Christian woman of adequate education who would be a good role model for other Indigenous people on the station and therefore they only considered an Aboriginal woman as a potential mate for him. In different intercultural contexts such as North America, there was some acceptance of interracial marriage, especially if it was a European man marrying an indigenous woman. ${ }^{29}$ A European woman marrying an indigenous man was, however, akin to being conquered by the 'other' race. ${ }^{30}$ As the historian Kate Ellinghaus has demonstrated, it was unthinkable for a middle-class European woman to marry an Aboriginal man in the late nineteenth and early twentieth centuries, for Aboriginal men were seen to be 'at the bottom of the scale, the extreme by which other inter-racial marriages were measured.' ${ }^{\prime 1}$ Those lower class European women who did marry Aboriginal men, she further argues, were considered either to have been eccentric, or to have inverted the normative gender roles. As women were seen to be carriers of racial identity in the nineteenth century, it was not possible for the missionaries to perceive of an interracial marriage for either male or female converts. In their desire to create a model Christian community, the Moravian missionaries at Ebenezer did not wish for the converts of the mission station to be assimilated into broader colonial society. Instead, they desired Aboriginal people to marry other Aboriginal people and stay attached to the mission station. The symbolic capital of Aboriginal Christian men and women was deemed too important to be lost within the broader civilising project of the colony. This was especially so as converted Aboriginal women were seen as gendered role models for other asyet-unconverted Aboriginal women.

There were, therefore, three major factors which led to the missionaries' choice of an Aboriginal wife for Nathanael Pepper: contemporary European cultural

28 Committee of the Melbourne Association 1863: 4.

29 Genetin-Pilawa 2008: 57-85.

30 See Alexander's discussion of Gaul in Alexander 2007: 216.

31 Ellinghaus 2006: 149. 
norms; contemporary racial expectations; and the need to retain Indigenous men and women on the stations as symbolic capital. In scouting for potential brides for their converts, the missionaries could not identify a single suitable, baptised Aboriginal woman amongst those women known to them, and thus the missionaries together with their supporters looked further afield. With the help of a Church of England minister, the Reverend Lloyd Chase, the Moravian missionaries came into contact with Mrs Anne Camfield, and her 'Institution for Native and Half-Caste Children', in which a number of unmarried Christian Indigenous women lived. This institution was established in 1852 near the present day town of Albany, some 430 kilometres south-east of Perth, in Western Australia, and some 3,000 kilometres west of Ebenezer on the other side of the continent. Camfield was an Anglican and opened the institution in a benevolent desire to provide for Aboriginal children. The institution included an orphanage and school and employed two Aboriginal assistants. Anne and her husband Henry provided shelter, food, education and care for 55 Indigenous children over almost 20 years. ${ }^{32}$ As with much of colonial Australia, the effects of colonisation in Western Australia greatly diminished Indigenous populations leaving many children without parental support, and even those with familial support were on occasion sent to European institutions in order to receive a Western education, often at the cost of Indigenous knowledge. Many of the children at Camfield's home were sent there in their infancy and thus were raised within a European cultural framework that was imbued with Christian teachings and norms.

In 1863, an orphaned woman, Rachel Wardekan, was sent over from the institution in Western Australia to be Pepper's wife. Deemed pious and Christian in nature, Wardekan was ideal for the civilising project. ${ }^{33}$ The young couple was married soon after she arrived at Ebenezer. This ritual was very much a public affair, and enacted the rites of passage of the normative Christian act. The very public element of the marriage was evident not only in the performative aspects of the wedding itself - which was staged in front of a large European and Aboriginal audience - but also within the expectations placed upon this union. The importance of their marriage was, according to contemporary commentators:

not to be measured by the amount of happiness it may confer on the young convert and his wife; but as they are living happily together, and setting a good example to the Blacks, it may well be anticipated that the words of Holy Scripture will be forcibly illustrated in the eyes of the heathen. ${ }^{34}$

Pepper and Wardekan were married to provide a good role model for their own people - except Wardekan was not of Pepper's people, and as her own associations to her people were severed when she was a child, her identity was replaced with that of 'Christian Aborigine'. After living and working on themission for a number of years, Wardekan died in $1869 .{ }^{35}$ Her legacy lived on

32 Harris 1990: 260-269.

33 For information about Rachel Wardekan see Harris 1990: 194, 202, 266.

34 Committee of the Melbourne Association 1863: 4.

3519 May 1864, Diary entry of A and M Hartmann, E Hartmann collection, 1979 [hereafter EHC], Box 2 of 4, Moravian Archives Bethlehem, United States of America [hereafter MAB]. 
through the fact that the perceived success of her translocation from Western Australia to Victoria resulted in further Indigenous women being sent some 3,500 kilometres to marry Indigenous men at the Ramahyuck mission station in Gippsland. Hagenauer had established this mission station in 1862 with the financial support of the Presbyterian Church and from this new mission station he continued his contact with Camfield with the hope of more brides being sent over for men on the Ramahyuck mission station. One man who was to receive a bride from Western Australia was Jimmy, who took the name James Mathew when he became the first convert at Ramahyuck in March 1866. Mathew was, according to Hagenauer, 'already greatly in love' with the woman whom Camfield would send to him, even though at that stage it was not certain of the two women sent over as to 'who's is Jimmys [sic]' wife. ${ }^{36}$ He was anxious to separate his imminent Christian conversion from his (material) desire to gain a wife. According to Hagenauer, 'he declares, however, that he always stopped here [at the mission] for Jesus sake and not for the sake of getting a wife. ${ }^{37}$ Although Hagenauer 'willingly believed' Mathew's claims, the association between Christianisation and obtaining material goods or wives was one made by Indigenous men themselves, demonstrating awareness of, and the ability to manipulate, the new social system evolving around them. This dual desire to get married and settle in houses was, according to Hagenauer, expressed not only by men upon the Ramahyuck mission station, but also on the government station of Corranderk. ${ }^{38}$ Thus, in Hagenauer's mind, the civilising mission had affected a desire amongst Indigenous men to marry in a Christian manner, and to live a sedentary life on a mission or on a government reserve.

The two women who were sent for the converted men Jimmy/Mathew and Charley/Charles Jacob died before the marriages could take place. ${ }^{39}$ Caroline, who was betrothed to Jacob, died of fever in Melbourne, with Chase stating that 'Instead of meeting her earthly bridegroom she met the Heavenly One.' ${ }^{40}$ Anna, the woman intended for Mathew, also died of fever in a Melbourne hospital before she could be united with her betrothed, and before she could be of potential benefit to the civilising mission. Hagenauer was particularly disappointed by the death of these women, not only because he had financed their transportation, but because it was a great blow to his expectations for the mission station. ${ }^{41}$ When reporting the death of Anna to a religious colleague, the Presbyterian Rev AJ Campbell, in Geelong in the Colony's south, Hagenauer expressed his distress, which was not directed towards the human loss of Anna - for Hagenauer had not met her personally - rather towards the loss of religious symbolic capital and also of funds. Yet even in his depressed state, he placed his faith in his omnipotent God, whose ways were 'very misterious [sic]

36 Hagenauer to Chase, 23 February 1866, Manuscript (MS) 3343, National Library of Australia [hereafter NLA].

37 Hagenauer to Chase, 23 February 1866, MS 3343, NLA.

38 Hagenauer to Campbell, 24 May 1866, MS 3343, NLA.

39 Hagenauer to Chase, 1 May 1866, MS 3343, NLA.

40 Hagenauer to Camfield, 21 May 1866, MS 3343, NLA.

41 Hagenauer to Campbell, 24 May 1866; Hagenauer to Reichel, 3 June 1866, MS 3343, NLA. 
and dark before us', yet ultimately would be revealed to those who waited. ${ }^{42}$ Hagenauer continued communicating with Camfield, and in 1867 the next group of Christian Aboriginal girls from Western Australian was sent to Ramahyuck, some of whom were seen as potential brides for converted Gunai/Kurnai men.

As the potential bridegrooms and brides were all converted to Christianity, or at least open to the Christian message, there was no prospect that either party to the marriage would have the ability to either convert their partner to Christianity or to draw them back into 'heathendom' ${ }^{43}$ The missionaries were concerned about apostasy - as evinced by their desire for both parties of a marriage to be Christian or under Christian instruction, not only so that they could be role models for other non-Christian Aborigines on the mission, but also to ensure that within the marriage the partners would be able to support each other in their individual and collective faith. Unlike some other religious groups, the Moravians did not practise mass conversion. The first converts of a Moravian mission station were expected to help spread the word of God amongst their fellow people and also to remain themselves as good role models for the other inhabitants of the mission. ${ }^{4}$ Yet within the mission structure the Indigenous convert was always subordinate to the European missionary, a fact attested to well into the nineteenth century by the pronounced absence of 'native churches' - those run by native people. This absence reflected an implicit belief that Indigenous people were incapable of running their own churches. ${ }^{45}$ The hierarchical structure of the mission was augmented by the sexist and racist norms of the nineteenth century. Indigenous men were not seen as being suitable marriage candidates for white women, and Indigenous women were not seen to be strong enough in moral character to resist the influences of European men within broader colonial society. Indigenous women were seen to be in need of marrying 'Christian Blacks', lest they fall 'prey to the evil passions of some bad whites.' 46 Thus, in the question of whom Indigenous women would marry, it was both the religiosity and race of the men which were important factors for the missionaries as they arranged Indigenous marriages.

\section{Under control: the marriages of Nora White, Rhoda Toby, Emily Peters and Ada Flower}

In 1867, five more Aboriginal women from Camfield's 'Institution for Native and Half-Caste Children' travelled to Ramahyuck where they were eagerly awaited by Hagenauer to be both brides for his converted men as well as role models for the Indigenous women on the mission station. Within this group was

42 Hagenauer to Campbell, 3 July 1866, MS 3343, NLA.

43 In the context of eighteenth century North America, Moravian missionaries there prevented marriages between Christian converts and non-Christian stating that it was 'against apostolic rule'. See Wheeler 2006: 163.

44 Vogt 2006: 17.

45 Libbey 1869: 13.

46 Hagenauer to Chase, 15 January 1867, MS 3343, NLA. 
Bessy Flower, who has been the subject of considerable academic scholarship as an Indigenous Christian role model as well as a subsequent rejecter of many of the controlling mechanisms of the missionary institution. ${ }^{47}$ Her story will not be repeated here. The marriages of the other four women - Nora White, Rhoda Toby, Emily Peters and Ada Flower - have received no extensive academic or public attention. The examination of their marriages from the perspective of the missionary provides insight into the gendered roles they were expected to fulfil upon missionary stations, and how arranged marriages were used to control women through inclusion within a Christian institution.

Nora White brought her infant child with her to Ramahyuck. Reading between the lines of the communication between Hagenauer and Camfield, it can be supposed that it was due to her predicament that she was sent over to Victoria with the hope that a Christian Aboriginal man would assume responsibility for her and that through such a marriage her respectability would once again be redeemed. Before White's arrival in Victoria, Hagenauer wrote to Camfield that he was:

glad [that] you have written as openhearted about your Nora and I can assure you that we fully understand from experience with the poor and weak Blacks how such matters are and how carefully they must be continu[ally] attended if they shall not fall a pray [sic] to the passions of others. However matters may stand with Nora as they may it shall not make any difference to me and I believe that if she is well, it would be best that her journey should not be delayed to[o] long. ${ }^{48}$

Thus, in Hagenauer's moral code, White's pregnancy was a consequence of her weakness of character, which reflected the inherent moral weaknesses of Indigenous people. She was, however, still deemed important to the civilising mission, and Hagenauer already had a young man in mind for her who was seen as being 'a very kindhearted man, and will only be to glad to get a wife who has been brought up well, the baby will not make any difference to him so.' ${ }^{49}$ Hagenauer suggested to Camfield that White and Rhoda Toby should travel together on the east-bound steamer. This would not only allow them to keep each other company, but - he insinuated - it would be better for their moral safety if they were in company. Eventually all five women were sent over together.

In July 1867, the same month in which the women arrived at Ramahyuck, both White and Toby were married to residents of the mission station. Following the lead of the public spectacle of Pepper and Wardekan's wedding, the double wedding ceremony was held in front of 150 'whites' and 70 'blacks'. White was joined in matrimony to Charley Foster, and Toby to a man called James. ${ }^{50}$ The spectacle was itself a public performance of the missionaries' optimism for a

47 Grimshaw 2004: 260-280; Grimshaw 2002: 12-18; Grimshaw and Nelson 2001: 295-309; Attwood 1986: 9-53.

48 Hagenauer to Camfield, 23 March 1867, MS 3343, NLA.

49 Hagenauer to Camfield, 22 April 1867, MS 3343, NLA.

50 Hagenauer to Mackie, 20 July 1867, MS 3343, NLA. 
model Christian family and the hope attached to the flourishing of the mission. The women were not, however, the model Christians that Hagenauer had wished for, and he noted to a religious peer that, although it was of benefit to have the women at the station, they were in need of more Christian tutelage than first anticipated. ${ }^{51}$ Within a year of Nora White's arrival, Hagenauer had become particularly disappointed in her. In his mind, she had been sent to Ramahyuck to fulfil her potential as a native Christian bride, yet he vilified her as having been 'the worst of them all' ${ }^{52}$ He believed that she was responsible for having persuaded more than 60 people to leave Ramahyuck in order to find financial self-support though working off the mission station. This irritated Hagenauer no end, for he wished for Aboriginal people to be willing to hear the word of God on the station, and more pragmatically, he needed people to undertake the agricultural work on the mission station. He also believed White had goaded him when she distributed 'her clothes among the women only to annoy and trouble' him..$^{53}$ The ambiguity of Hagenauer's Christian norms is evident in this episode insofar as the teachings of Christianity require people to care for their neighbours and help those in need. However, when White distributed her personal goods amongst other people on the mission station, Hagenauer - we can only image - deemed her to be shedding her markers of European civilisation, and thus deemed her to be upsetting his authority upon the station. His rules were not always defined, leaving uncertainty as to behavioural expectations. In this situation it is clear that White's form of communal behaviour was not Hagenauer's. For Hagenauer, White's conduct was deplorable on both religious and moral levels. He saw her to be a bad influence on other Aboriginal women and as inciting insubordination amongst the residents of the mission. Hagenauer lamented to Ann Camfield, that,

[regarding] poor Nora, I do not know what to do especially as I have no legal power over her. Her husband wept about it and said she was making him miserable and bad, but he would not leave her because she was his wife, and I think he is correct. We must hope with her for the best. ${ }^{54}$

In this quote, there is an inversion of the gendered norms within marriage, as White's husband Charley Foster is engaged in an emotive response to his wife's corrupting, and implicitly promiscuous, behaviour and thus elicits the sympathy of the reader. However, emotive responses were also a mark of the evangelical religiosity of the Moravian Church, and therefore Foster's weeping denotes not only his feminine, disempowered position within his marriage, but also as his attachment to Christian modes of religious engagement. His emphatic desire not to leave White because she was his wife, reiterates his position as a good Christian who was holding firm to his religious norms, despite the obvious disregard that his wife had for the institution. The 'best' which Hagenauer had

51 Hagenauer to Mackie, 20 July 1867, MS 3343, NLA.

52 Hagenauer to Camfield, 6 February 1868, MS 3343, NLA.

53 Hagenauer to Camfield, 6 February 1868, MS 3343, NLA.

54 Hagenauer to Camfield, 6 February 1868, MS 3343, NLA. 
hoped for in relation to White was that she could have become a role model of the submissive Christian woman. This was not, however, the mould in which White wished to be cast. Hagenauer's desire to maintain the moral order of society was ineffective, for he had 'no legal power over her'. As British subjects, Australian Aborigines were to be treated as such, yet from 1869 and into the 1880 s a number of laws specifically curtailed the rights of Aboriginal people, including rights of residency, rights of access to material goods, and rights as parents, for the government could forcibly remove children. ${ }^{55}$ However, these laws were some years off. In his disempowerment at that time, Hagenauer reverted to slander. In February 1868, he complained that 'Nora especially is worst [sic] than any other common bad lubras [Aboriginal women] in the district, and has given much anxiety to all of us.56 By vilifying White through the derogative term of 'bad lubra', ${ }^{57}$ Hagenauer placed himself on a moral and spiritual high-ground, and thereby marginalised her further from his normative religious and moral codes.

Rhoda Toby was also seen as having been a less than ideal role model for other women on the station. She, along with White, had incited people to leave the station at the end of 1867, and Hagenauer was also disappointed in her. He was further disappointed that she neglected her religious obligations and did not attend church services. He had, however, some hope that she would be capable of being rehabilitated into his moral and religious codes, especially if she were to receive a 'kind' letter from Mrs Camfield, which Hagenauer deemed would 'set her right and bring them back again to the station.' ${ }^{58}$ The tactic that Hagenauer employed here was one of coaxing through a third person, who had acted as a mother to the women. He was not able to threaten Toby with such actions as excommunication, which would have signified the loss of his approval, for Toby was already guilty in Hagenauer's eyes of neglecting her Christian duties, and thus would not have been affected by any further loss of missionary approval. Hagenauer hoped to curtail both Toby and her husband through directing the cajoling attention of a third person onto Toby alone.

In Hagenauer's pronouncements, it was always the women who were to blame. He complained that White and Toby were seen to have 'persuaded their husbands to leave the station and find work somewhere else', and not long after, 'their husbands were very sorry for the demands of their wives' ${ }^{59}$ Thus, although Hagenauer used marriage as an agent of control over Indigenous women, the women themselves were not controlled by marriage and could subvert this institution through influencing their husbands to adhere to their wishes - ones that must have always held the potential to clash with Hagenauer's ideals for the social positions of Indigenous people.

55 McCorquodale 1986: 11.

56 Hagenauer to Mackie, 4 February 1868, MS 3443, NLA.

57 The term 'lubra' was used within colonial Victoria to denote a female Aboriginal person and due to its non-personal nature was derogatory. See Philips 1987: 40.

58 Hagenauer to Camfield, 6 February 1868, MS 3343, NLA.

59 Hagenauer to Camfield, 6 February 1868, MS 3343, NLA. 
There had been no potential spouse awaiting Emily Peters when she arrived with the others at Ramahyuck. However, Hagenauer was soon concocting a plan for her to be safely within the confines of a morally upstanding Christian marriage. In reporting to Camfield about how the very public weddings of White and Toby had raised awareness of the plight of Christian Aborigines on the mission, he stated:

In reference to Emily I feel sure you will be glad that she is here safely, for Mrs Hagenauer has great fears that it may be with her as it was with Nora, when she came to you from the bush, and I thought best to tell Mr Chase about it. For the present it must be kept secret: so please do not mention it to anyone, it may not be so after all. Should it be as I suppose it would be best to get her soon married. ${ }^{60}$

In this letter, Hagenauer insinuated that Peters was pregnant. As she was not married this supposed pregnancy marked her as not adhering to Christian moral and sexual codes, and therefore not yet fully out of the clutches of 'heathendom'. We can also read these remarks as reflections of Hagenauer's own ideas of sex, gender, marriage, race and Christian morality. It does not appear that Peters was pregnant at this stage, although Hagenauer was keen to ensure that she would not fraternise with the opposite sex, and that any sexual intercourse would only occur within the institution of marriage. Moreover, as the sexual experiences of single women in the nineteenth century were positioned outside of the 'normative boundaries of womanhood', ${ }^{61}$ Hagenauer desired for Peters to be married as soon as possible in order for her to reposition herself within religious and cultural norms, and thereby to ensure that she would be utilisable as a role model for Aboriginal women on the station. In February 1868, Hagenauer communicated with Camfield that,

Emily was off with Nora, who had been about the home for a long time. Our windows are all nailed and the doors locked but she ran away before the door was shut. Bessy [Flower] and I went to where the Camp is and I stated that if Emily was not back in the morning I would send the Police ... In the presence of the Magistrate we asked [Emily Peters] kindly about everything and after earnest and full consideration we found the best would be to get her married, and under these circumstances I trust, my dear Mrs Campfield [sic] you give you consent to it. She was in love with Allen and he is a good man, therefore I thought it would be the best to get her out of temptation. ${ }^{62}$

Hagenauer had boarded up the windows and locked all the doors to ensure that Peters was forcefully kept within the building and 'out of temptation', with Hagenauer insinuating that this temptation was of a sexual nature. In running away before she could be locked in, Peters showed her defiance to Hagenauer's

60 Hagenauer to Camfield, 20 July 1867, MS 3343, NLA.

61 Fink and Holden 1999: 234.

62 Hagenauer to Camfield, 6 February 1868, MS 3343, NLA. 
normative moral codes, which were not influential enough to curtail Peters's resistance to the enforcement of the dominant religious hegemony. As his religious influence over Peters appeared to be ineffective, Hagenauer tried to influence her through turning to the political realm. In order to get Peters to adhere to the moral order of society, Hagenauer interviewed her 'in the presence of the Magistrate', coming to the conclusion that marriage would be the most suitable avenue to 'get her out of temptation', and thus to control her sexually. In colonial Victoria, there was no law forbidding miscegenation, nor a law which prescribed that Aboriginal people needed to receive permission from a governmental authority to marry. By the 1880s, however, it would be increasingly common for governmental officials to interfere with the potential matches between Indigenous people, especially those of mixed racial heritage. ${ }^{63}$ Although Hagenauer's action of taking Peters to the magistrate was a legally empty threat, it was nevertheless a threat, and an indication that he wished to control her through marrying her off to a suitor of his choice.

Ada Flower was also deemed old enough to be married, with Hagenauer wishing that there was 'another baptized man here who would keep her comfortable and on the Station'. Once this had transpired he believed 'things would be right'. However, with 'the very bad influence of Nora and the temptations from the heathen men it is not possible to keep [Ada out of temptation]. ${ }^{\prime 64}$ Once again, Hagenauer's normative moral structure becomes evident. As these Aboriginal women were seen to have been lacking Christian virtues and Victorian prudishness, it was thought that only through marriage would they be immune from the 'temptations from the heathen men', and beyond the reach of the 'very bad influences' of other females. By February 1868, Hagenauer's wish for Peters was fulfilled as she was controlled through marriage, not to Allen, but to John Ellis, who in Hagenauer's words was 'a nice blackfellow and a candidate for baptism' 65 - thus, obviously a man who had potential to become a fully fledged Christian. Ellis was to be the first of Peters's four husbands, and one with whom she would have one of her 16 children. It must be noted that the sheer number of men to whom Peters was joined in matrimony demonstrated her own regard for the institution of marriage, and thus from her perspective marriage may not have had the controlling connotations that Hagenauer's perspective on marriage encompassed. ${ }^{66}$ Yet marriage was not the only instrument open to Hagenauer to curtail the rebellious nature of 'his' charges. In 1878, he banished Peters, along with her second husband, James Brindle, and their family from Ramahyuck, as they had been party to a letter of complaint written against Hagenauer and addressed to the Board for the Protection of Aborigines. ${ }^{67}$ Hagenauer did not respond kindly to this act of insubordination, and effectively excluded Peters from the mission station, thereby discounting her as a potential role model for other Indigenous people at Ramahyuck. Through banishing Indigenous people

63 Ellinghaus 2001: 22-29.

64 Hagenauer to Camfield, 6 February 1868, MS 3343, NLA.

65 Hagenauer to Mackie, 4 February 1868, MS 3443, NLA.

66 Nelson et al 2002: 318.

67 Nelson et al 2002: 48. 
from the mission stations for insubordination, Hagenauer, along with other missionaries in the colony, was able to maintain a controlled environment in which there was no place for people who questioned the moral authority of the reigning missionary. ${ }^{68}$ Initially Hagenauer had used inclusion through marriage as a tactic to control Indigenous women, but as time progressed and the women continued to defy his control, he reverted to more common methods exercised by missionaries across the world, such as exclusion through excommunication, or banishment.

\section{Controlling marriage}

Marriage can be used to achieve upward mobility and independence. This is evident in the fact that many lower class women in mid- to late-nineteenth century England actively pursued relationships which they perceived to have held potential financial benefits. ${ }^{69}$ Beyond and above the perceived individual material benefits of marriage there were also larger social ties involved, as women took on their husband's social and cultural group after marriage. In introducing Western European ideas of marriage to Australian Aborigines, the Moravian missionaries drew on Indigenous traditions of formalised relationships that ensured the maintenance of complex social structures as well as exogamy. The missionaries, however, also brought with them racial and gendered ideas of Western European Christian marriages into which they placed Indigenous people on the mission station. Hagenauer's motivation for much of his matchmaking was connected to his desire to have a well ordered mission in terms of gendered roles and of people adhering to his strict discipline. He followed Moravian norms that saw marriage as an institution that benefit the community, yet he also expressed his individual desires as to whom the women should be married, and the timing of their marriages was also determined by his desire to control the women's sexuality or insubordination. The cases of the Aboriginal women presented here demonstrate that intra-racial marriages upon the mission station were used to reproduce European racial and gendered categories through the prism of religion. These case studies also demonstrate that Indigenous women were considered differently to Indigenous men, who were to receive a wife as a reward for converting to Christianity. In describing the progress of the five women to a religious colleague in 1877, Hagenauer's disappointment was evident. Flower, he stated, was doing well and she had married Donald Cameron, who was Hagenauer's right hand man. The two had been in charge of the orphan home for Aboriginal children, but Flower had tired of this role. Bessy's sister Ada had passed away. White and Peters, it was said, both had big families, yet neglected their children and made trouble for Hagenauer. He wrote nothing of Peters, yet, as we have read above, she and her husband would be expelled from the mission in 1878 for raising their dissenting voices. ${ }^{70}$

68 For an example of another missionary banishing Aboriginal people from a mission station for an act of insubordination see: Philips 1987: 46.

69 Frost 1994: 224-245.

70 Hagenauer to Chaunery, 16 October 1877, MS 3343, NLA. 
Before the women fell out of favour with Hagenauer, he had expressed hope for them all in contributing to the mission station. The unmarried single mother Nora White was quickly married off once she arrived at Ramahyuck, and through the ritualised ceremony redeemed her decency in the eyes of the missionary, and thus was capable of being seen as a role model for other women on the mission. Hagenauer deemed Emily Peters to be in need of marriage after she began to express her sexual desires, and in order to 'get her out of temptation', he saw marriage as an effective way of controlling her sexuality. These women were of use to Hagenauer's mission through their roles in establishing Christian nuclear families and adhering to Christian norms. Although there were slightly different motivations behind marrying off each of these women, all of these marriages assisted Hagenauer in controlling the lives of these women. From the existing sources, it seems that the women had little agency in their betrothals, reflecting not only Moravian marriage traditions, but also some middle class English traditions, as well as some traditional Aboriginal traditions. To various degrees all the women seemed to have had some respect for the institution of marriage, with Emily Peters and her four marriages a case in point.

Marriage also bound these women geographically; initially to the location of the mission station, and when these ties were broken, the women were bound through marriage within the political entity of the Colony of Victoria, with no recourse to return to Western Australia. Around the time the women were married, there was an increased anxiety about how to manage the Indigenous population of Victoria, as indicated by the increasingly stringent and radicalised laws of 1869 and $1886 .{ }^{71}$ The 1886 Act known as the 'Half-Caste Act' legally differentiated between so-called 'full' and 'halfcaste' Aborigines, and coincided with a stricter control over all aspects of Indigenous people's lives, partly in order for the state to reduce its financial obligations to Indigenous peoples, partly in response to the racist attitudes of colonists. ${ }^{72}$ Hagenauer, as an advisor to the Board for the Protection of the Aborigines, took part in drafting this Act, and his contribution consequently betrays his assimilationist views. ${ }^{73}$ These views were in turn a change from his views of the early 1860s, in which intra-racial Christian marriages were the desired way to draw Aboriginal men and women further under the missionary's control on the mission station through the institution of Christian marriage.

\section{Conclusion}

Matrimony has a multiplicity of meanings as well as expectations placed upon it, not least those placed upon it by Christian missionaries. The missionary examined here, Hagenauer, used marriage to redeem reputations, control sexuality, punish perceived licentious and insubordinate women, create role

71 Aborigines Protection Act, 1869 (Vic); Aborigines Protection Act, 1886 (Vic).

72 Ellinghaus 2001: 22-29.

73 Jensz 2010: esp Chapter 6. 
models and to perpetuate racial and gendered norms. Recently there has been more academic attention placed on the roles of intimacy and sexual morality within colonial spaces, including how interracial marriages in the nineteenth century helped define and reflect cultural norms. ${ }^{74}$ There has also been some attention placed more specifically on the interracial marriages within nineteenth century Australia. ${ }^{75}$ There has, however, been little attention placed on arranged Indigenous intra-racial marriages facilitated by Europeans in the nineteenth century. In examining the arrangement of such marriages, the shifting attitudes toward Indigenous women becomes apparent. Hagenauer's initial response to the women was to control them and their sexuality through marriage, and thereby to include them into the Christian mission as role models for other Indigenous women. The women themselves, however, were not controlled by marriage and after marrying Indigenous men connected to the mission station these women continued to maintain strong voices in opposition of what Hagenauer desired them to become. When Hagenauer's tactic of marriage as an instrument of control failed, he reverted to standard missionary tactics such as exclusions and threats. Initially, however, Hagenauer wished to include Indigenous women into the Christian mission in order to achieve his goal of 'raising' the 'heathen' to European norms. The Christian institution of marriage offered Hagenauer a seemingly benevolent yet ultimately manipulative method of establishing and maintaining control over the lives of Indigenous women.

\section{References}

\section{Archival sources}

Hagenauer Letter Book, MS 3343, National Library of Australia, Canberra.

Hartmann Diary, E Hartmann collection (Box 2 of 4), Moravian Archives, Bethlehem, Pennsylvania, United States of America.

Moravian Microfilm Collection, Aboriginal Affairs Victoria.

Protocoll des Missionsdepartements, Unitäs Archiv, Herrnhut, Germany.

Protocoll der Unitätsaeltesten Conferenz, Unitäs Archiv, Herrnhut, Germany.

\section{Periodicals}

Missionsblatt

74 See for example, Alexander 2007: 213-211; Ballantyne and Burton 2009; Ellinghaus 2006; Genetin-Pilawa 2008: 57-85; Grimshaw 2002: 12-28; Stoler 1989: 634-660; Wanhalla 2008: 34-56.

75 Ellinghaus 2003: 183-207. 
ABORIGINAL HISTORY 2010 VOL 34

\section{Legislation}

Aborigines Protection Act 1869 (Vic)

Aborigines Protection Act 1886 (Vic)

\section{Secondary Sources}

Alexander, Elizabeth 2007, 'For better or for worse: marriage across boundaries', Journal of Women's History 19(3): 213-221.

Attwood, Bain 1986, ““. ...In thename of all my coloured brethren and sisters”: a biography of Bessy Cameron', Hecate: A Women's Interdisciplinary Journal 12(1-2): 9-53.

Ballantyne, Tony and Antoinette Burton (eds) 2009, Moving Subjects: Gender, Mobility, and Intimacy in an Age of Global Empire, University of Illinois Press, Urbana \& Chicago.

Bettermann, Wilhelm 1931, 'Das Los in der Brüdergemeine', Zeitschrift für Volkskunde III(3): 284-287.

Beyreuther, Erich 1962, 'Lostheorie und Lospraxis', in Studien zur Theologie Zinzendorfs: Gesammelte Aufsätze, Erich Beyreuther (ed), Verlag der Buchhandlung des Erziehungsvereins Neukirchen-Vluyn, Neukirchen Vluyn: 109-139.

Blake, LJ 1972, 'Hagenauer, Friedrich August (1829 - 1909)', Australian Dictionary of Biography, vol 4, Melbourne University Press, Melbourne: 314-315.

Committee of the Melbourne Association in Aid of the Moravian Mission to the Aborigines of Australia 1863, Further facts relating to the Moravian Missions in Australia. Read in connection with the report of the Committee at the annual meeting of the Melbourne Association in Aid of the Moravian Mission to the Aborigines of Australia, Held August 17, 1863, Fergusson \& Moore, Melbourne.

Ellinghaus, Katherine 2001, 'Regulating Koori marriages: the 1886 Victorian Aborigines Protection Act', Journal of Australian Studies 67: 22-29.

- 2003, 'Absorbing the 'Aboriginal problem': controlling interracial marriage in Australia in the late 19th and early 20th centuries', Aboriginal History 27: 183-207.

- 2006, Taking Assimilation to Heart: Marriages of White Women and Indigenous Men in the United States and Australia, 1887-1937, University of Nebraska Press, Lincoln \& London.

Erlank, Natasha 2003, 'Sexual misconduct and church power on Scottish mission stations in Xhosaland, South Africa, in the 1840s', Gender \& History 15: 69-84. 
Fink, Janet and Katherine Holden 1999, 'Pictures from the margins of marriage: representations of spinsters and single mothers in the mid-Victorian novel, interwar Hollywood melodrama and British film of the 1950s and the 1960s', Gender $\mathcal{E}$ History 11: 223-255.

Frost, Ginger S 1994 "“I shall not Sit Down and Crie": women, class and breach of promise of marriage plaintiffs in England, 1850-1900', Gender and History 6: 224-245.

Genetin-Pilawa, C Joseph 2008, '“All intent of seeing the White Woman married to the Red Man": the Parker/Sackett Affair and the public spectacle of intermarriage', Journal of Women's History 20(2): 57-85.

Grimshaw, Patricia 2002, 'Interracial marriages and colonial regimes in Victoria and Aotearoa/New Zealand', Frontiers 23(3): 12-14.

- 2004, 'Faith, missionary life, and the family', in Gender and Empire, Philippa Levine (ed), Oxford University Press, Oxford: 260-280.

- and Elizabeth Nelson 2001, 'Empire, "the civilising mission" and Indigenous Christian women in colonial Victoria', Australian Feminist Studies 16(36): 295-309.

Harris, John 1990, One Blood. 200 Years of Aboriginal Encounter with Christianity: a Story of Hope, Albatross, Sutherland.

Hassé, ER 1897, Women's Work in the Foreign Missions of the Moravian Church: paper read at the Free Church Council March 9th, 1897, Griffin \& Sheard, Ashton-under-Lyne.

Holmes, John 1818, Historical Sketches of the Missions of the United Brethren for Propagating the Gospel among the Heathen, from their commencement to the present time. Dublin, R Napper.

Howitt, AW 1996[1904], The Native Tribes of South-East Australia, Aboriginal Studies Press, Canberra.

Jensz, Felicity 2010, German Moravian Missionaries in the British Colony of Victoria, Australia, 1848-1908: Influential Strangers, Brill, Leiden.

Libbey, John 1869, The Missionary Character and the Foreign Mission Work of the Church of the United Brethren (of Moravians), Moravian Church Dublin, Dublin.

McCorquodale, John 1986, 'The legal classification of race in Australia', Aboriginal History 10(1): 7-24.

Mettele, Gisela 2009, Weltbürgertum oder Gottesreich: Die Herrnhuter Brüdergemeine als globale Gemeinschaft 1727-1857, Vandenhoeck \& Ruprecht, Göttingen. 
Nelson, Elizabeth, Sandra Smith and Patricia Grimshaw (eds) 2002, Letters from Aboriginal Women of Victoria, 1867-1926, The History Department, University of Melbourne, Melbourne.

Peucker, Paul 2006, "“Inspired by flames of love”: homosexuality, mysticism, and Moravian Brothers around 1750', Journal of the History of Sexuality 15: 30-64.

Philips, David 1987, 'Sex, race, violence and the criminal law in colonial Victoria: anatomy of a rape case in 1888', Labour History 52: 30-49.

Podmore, Colin 1998, The Moravian Church in England 1728-1760, Clarendon Press, Oxford.

Sayre, Gordon 1998, 'Native American sexuality in the eyes of the beholders, 1553-1710', in Sex and Sexuality in Early America, Merril D Smith (ed), New York University Press, New York: 35-54.

Schutt, Amy C 2004, 'Female relationships and intercultural bonds in Moravian Indian missions', in Friends E Enemies in Penn's Woods: Indians, Colonists, and the Racial Construction of Pennsylvania, William A Pencak and Daniel K Richter (eds), The Pennsylvania State University Press, University Park, PA: 87-103.

Spangenberg, August Gottlieb 1840, Instructions for Missionaries of the Church of the Unitas Fratrum, or United Brethren, Brethren's Society for the Furtherance of the Gospel among the Heathens, London.

Stoler, Ann L 1989, 'Making empire respectable: the politics of race and sexual morality in 20th-century colonial cultures', American Ethnologist 16(4): 634660.

Vogt, Peter 2006, "“Everywhere at home”: the eighteenth century Moravian movement as a Transatlantic religious community', Journal of Moravian History 1: 7-29.

Wanhalla, Angela 2008, "“One white man I like very much": intermarriage and the cultural encounter in southern New Zealand, 1829-1850', Journal of Women's History 20(2): 34-56.

Wheeler, Rachel 2006, To live upon hope: Mohicans and Missionaries in the EighteenthCentury Northeast, Cornell University Press, Ithaca \& London. 